\title{
Forcing of dissolved organic carbon release by phytoplankton by anticyclonic mesoscale eddies in the subtropical NE Atlantic Ocean
}

\author{
S. Lasternas ${ }^{1}$, M. Piedeleu ${ }^{2}$, P. Sangrà ${ }^{2}$, C. M. Duarte ${ }^{1,3}$, and S. Agustín ${ }^{1,4}$ \\ ${ }^{1}$ Global Change Research Department, IMEDEA (CSIC-UIB), Miquel Marqués 21, 07190 Esporles, Spain \\ ${ }^{2}$ Instituto Universitario de Oceanografía y Cambio Global (IOCAG-ULPGC), Universidad de Las Palmas de Gran Canaria, \\ Las Palmas de Gran Canaria, Spain \\ ${ }^{3}$ The UWA Oceans Institute, The University of Western Australia, 35 Stirling Highway, 6009 Crawley, Australia \\ ${ }^{4}$ The UWA Oceans Institute and School of Plant Biology, The University of Western Australia, 35 Stirling Highway, \\ 6009 Crawley, Australia
}

Correspondence to: S. Lasternas (sebastien@imedea.uib-csic.es)

Received: 10 July 2012 - Published in Biogeosciences Discuss.: 3 August 2012

Revised: 11 January 2013 - Accepted: 7 March 2013 - Published: 27 March 2013

\begin{abstract}
The organic carbon fluxes mediated by planktonic communities in two cyclonic eddies (CEs) and two anticyclonic eddies (AEs) at the Canary Eddy Corridor were studied and compared with the dynamics in two far-field (FF) stations located outside the eddies. We observed favorable conditions and signs for upwelling at the center of CEs and for downwelling and mixing at the centers of AEs. CEs were characterized by a higher concentration of nutrients and the highest concentration of chlorophyll $a(\operatorname{chl} a)$, associated with the highest abundance of microphytoplankton and diatoms. AEs displayed concentrations of $\operatorname{chl} a$ values and nutrients similar to those at the FF stations, except for the highest ammonium concentration occurring at $\mathrm{AE}$ and a very low concentration of phosphorus at FF stations. AEs were transient systems characterized by an increasing abundance of picophytoplankton and heterotrophic bacteria. While primary production was similar between the systems, the production of dissolved organic carbon $\left(\mathrm{P}_{\mathrm{DOC}}\right)$ was significantly higher in the AEs. Phytoplankton cell mortality was lowest in the $\mathrm{CEs}$, and we found higher cell mortality rates at $\mathrm{AE}$ than at FF stations, despite similar chl $a$ concentration. Environmental changes in the AEs have been significantly prejudicial to phytoplankton as indicated by higher phytoplankton cell mortality ( $60 \%$ of diatoms cells were dead) and higher cell lysis rates. The adverse conditions for phytoplankton associated with the early-stage anticyclonic systems, mainly triggered by active downwelling, resulted in higher cell mortality, forcing photosynthesized carbon to fuel the dissolved pool.
\end{abstract}

\section{Introduction}

The dynamics of mesoscale eddies exert profound influences on the vertical fluxes of organic matter, nutrients and carbon (Owen, 1981; Arístegui et al., 2003; Martin and Richards, 2001; Mathis et al., 2007; Alonso-González et al., 2010; Benitez-Nelson and McGillicuddy, 2008) and may modulate the oceanic vertical pump (Oschlies and Garçon, 1998). Previous studies have indicated the importance of mesoscale eddies in ocean biogeochemistry by modulating the efficiency of the biological pump. Indeed, cyclonic eddies (CEs) tend to promote the biological pump by increasing nutrient supply, thereby enhancing the primary production (Smith et al., 1996; Garçon et al., 2001; McGillicuddy et al., 2007) and by favoring larger phytoplankton cells (Rodríguez et al., 2001; Vaillancourt et al., 2003). Anticyclonic systems are mostly oligotrophic structures characterized by nutrient-poor surface waters (Falkowski et al., 1991; McGillicuddy et al., 1998), constraining primary production and frequently associated with relatively intense bacterial abundance and production (Bidigare et al., 2003; Ewart et al., 2008; Baltar et al., 2010).

The Canary Archipelago is a continuous source of mesoscale eddies generated by the Canary Current and of the trade wind perturbations by the islands' topography (Jiménez et al., 2008; Piedeleu et al., 2009) and the main pathway of long-lived eddies in the subtropical northeast Atlantic, originating at the Canary Eddy Corridor (Sangrà et al., 2009). La Palma, El Hierro, Tenerife and Gran Canaria islands, where 
surveyed eddies have been located, may be viewed as tall deep islands due to their steep and higher topography. The presence of a strong surface wind shear/curl cells has been documented in these islands' lees during summer (Basterretxea et al., 2002; Jiménez et al., 2008; Mason et al. 2001). On the basis of a submesoscale resolution quasi-synoptic temperature section crossing the Gran Canaria wake, Basterretxea et al. (2002) observed evidence of downward/upward lineal Ekman surface-layer pumping coinciding with strong anticyclonic/cyclonic wind shear regions. Additional studies have been initiated at this zone to better understand the implication of counter-paired cyclonic and anticyclonic eddies for biological processes and to address their influence in carbon fluxes. Cyclonic eddies promoted nutrient pumping and vertical uplifting of the deep chlorophyll maximum, increasing plankton production, while anticyclonic eddies (AEs) tended to accelerate downstream transport below the photic zone (Arístegui et al., 1997; Arístegui and Montero, 2005; González-Dávila et al., 2006). Since anticyclonic structures can be long-lived coherent structures lasting several months (Sangrà et al., 2005, 2009), the magnitude and the efficiency of biological processes such as production and health status of communities can be affected for extended periods and may consequently have significant implications in carbon fluxes.

In the present study, we aim to explore whether anticyclonic eddies may affect the physiological status of phytoplankton and heterotrophic bacteria cells by stressing populations as a consequence of the downstream processes and the associated decline of nutrient concentrations. We do so by characterizing the hydrological conditions and physical features of the eddy systems along with the nutrient availability and biological processes at the euphotic zone within cyclonic and anticyclonic systems of the Canary eddy fields, and by comparing them to similar processes in waters outside the eddy systems. Specifically, we quantify the abundance and physiological status of heterotrophic bacteria and phytoplankton and its community structure, as well as the production of dissolved organic carbon $\left(\mathrm{P}_{\mathrm{DOC}}\right)$, linking these two components of the planktonic food web.

The status of phytoplankton cells is emerging as a key driver determining the flow of carbon from primary producers to phytoplankton, as indicated by phytoplankton mortality and cell lysis during stress (e.g. Agustí et al., 2001). Both mechanisms are perceived to be important loss processes (Proctor and Fuhrman, 1991; Brussaard et al., 1995; Agustí et al., 1998; Agustí and Duarte, 2000) and increase the proportion of primary production that flows to the dissolved pool as $\mathrm{P}_{\mathrm{DOC}}$. Phytoplankton health status is likely dependent on the presence of stressors, such as reduced nutrient availability (Myklestad, 1977), or incident UVB and PAR radiation (Berges and Falkowski, 1998; Llabrés and Agustí, 2006). Hence, changes in hydrological properties occurring at anticyclonic systems and affecting nutrient availability of the exposure of phytoplankton cells to intense UVB and PAR radiation may stress phytoplankton cells, resulting in subsequent losses through cell mortality and lysis.

The examination of the physiological status of phytoplankton and bacteria cells in eddy systems may thus provide insights into the consequences of eddy dynamics for carbon fluxes in the ocean. We, therefore, examined anticyclonic and cyclonic eddies in the Canary eddy field to test for differences in the production of carbon and physiological status of phytoplankton and heterotrophic bacteria. In particular, we examined particulate and dissolved primary production, phytoplankton lysis rates and the percentages of living and dead phytoplankton and heterotrophic bacteria cells. We examine here the relationship between phytoplankton cell mortality, lysis rates and the $\mathrm{P}_{\mathrm{DOC}}$ by phytoplankton, on the one hand, and their relationship with the status of bacteria cells on the other. We examined these properties in two anticyclonic and two cyclonic eddies in the Canary eddy field as well as at two far-field (FF) locations, in order to examine these properties in the absence of eddy forcing.

\section{Materials and Methods}

\subsection{Description of the cruise track and eddies}

Sampling was conducted at stations located at the subtropical northeast Atlantic, in the Canary Islands region (Fig. 1), on board the R/V Hespérides during the RODA-1 (Remolinos Oceánicos y Deposición Atmosférica) cruise from 11 August to 5 September 2006. The biological and chemical characteristics of eddies were studied in two cyclonic eddies (CE1, CE2), two anticyclonic eddies (AE1, AE2), and two stations away from the perturbed region by the Island, named undisturbed far-field stations (FF1, FF2; Fig. 1). To identify the eddy fields and investigate the initial hydrographic structure of cyclonic and anticyclonic eddies shed by the Canary Islands, their lee waters were first surveyed using real-time sea surface temperature (SST). These images allowed us to detect the surface signature of four eddies: two cyclonic eddies, one in the lee of Gran Canaria (CE1) and another west of La Palma (CE2), and two anticyclonic eddies, located southeast of El Hierro (AE1) and southwest of Gran Canaria (AE2) (Fig. 1). During each survey we sampled sections of 9 to 13 expendable bathythermographs (XBTs) or CTD stations across the estimated eddy centers. The XBT probes provided the temperature of the water column down to a depth of $700 \mathrm{~m}$, while CTD probes reached $1000 \mathrm{~m}$ depth (Figs. 2a, $\mathrm{c}$ and $3 \mathrm{a}, \mathrm{c})$. Temperature anomalies were calculated using the most distant section stations from the eddy centers as reference, where minimums in the isotherm perturbation were encountered (Figs. 2b, d and 3b, d). These parameters were used to estimate the maximum depths of the eddy and the diameter of the mesoscale structures (Table 1). Mixed layer depths were calculated using the method of Kara et al. (2000) and checked visually. Wind curl fields were derived from 


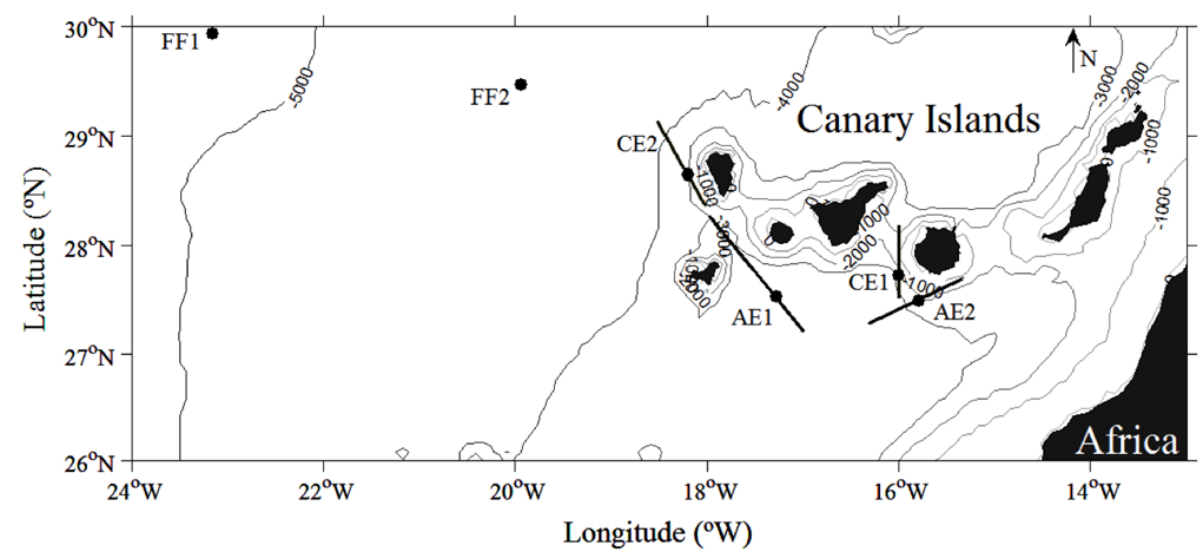

Fig. 1. Observational domain. Black dots indicate the location of the biogeochemical stations at the far-field (FF1, FF2) and at the center of the cyclonic eddies (CE1, CE2) and anticyclonic eddies (AE1, AE2). Black lines indicates the location of the XBT transects crossing the eddies.

Cross-Calibrated Multi-Platform gridded surface wind vectors field (CCMP-Winds) provided by PODAAC/JPL-NASA (ftp://podaac-ftp.jpl.nasa.gov/allData/ccmp), and a level 3.5a product - that is, $0.25^{\circ}$ gridded data averaged over 5 days and including QuickScat data - was used. Instantaneous wind vectors were also derived along the eddies' transects from the onboard meteorological station.

\subsection{Biogeochemical sampling}

At the 6 stations (CE1, CE2, AE1, AE2, FF1 and FF2), vertical profiles of temperature, salinity, and fluorescence down to $200 \mathrm{~m}$ depth were performed using a Seabird 911 Plus conductivity-temperature-depth (CTD) system. The fluorescent profiles were used to estimate the deep chlorophyll maximum (DCM) depths. Seawater samples were collected in $12 \mathrm{~L}$ Niskin bottles mounted on a General Oceanics rosette sampler, at 5 to 6 depths from the surface to $150 \mathrm{~m}$ selected as a function of the depth of the deep fluorescence maximum. Samples for nutrient analysis (phosphate, nitrate + nitrite, ammonium and silicate) were collected at 6 depths down to $150 \mathrm{~m}$. Samples for the determination of the dissolved inorganic phosphate concentrations and the nitrate + nitrite concentrations were kept frozen until analyzed in a Bran + Luebbe AA3 autoanalyzer following standard spectrophotometric methods (Hansen and Koroleff, 1999), and ammonium concentrations were measured spectrofluorometrically within $1 \mathrm{~h}$ of collection following Kérouel and Aminot (1997).

Samples of $200 \mathrm{~mL}$ of water from 6 depths were filtered through Whatmann GF/F filters to estimate total chlorophyll $a$ concentration (chl $a$ ) and extracted for $24 \mathrm{~h}$ in $90 \%$ acetone for fluorometric determination (Turner Designs fluorometer) following Parsons et al. (1984).

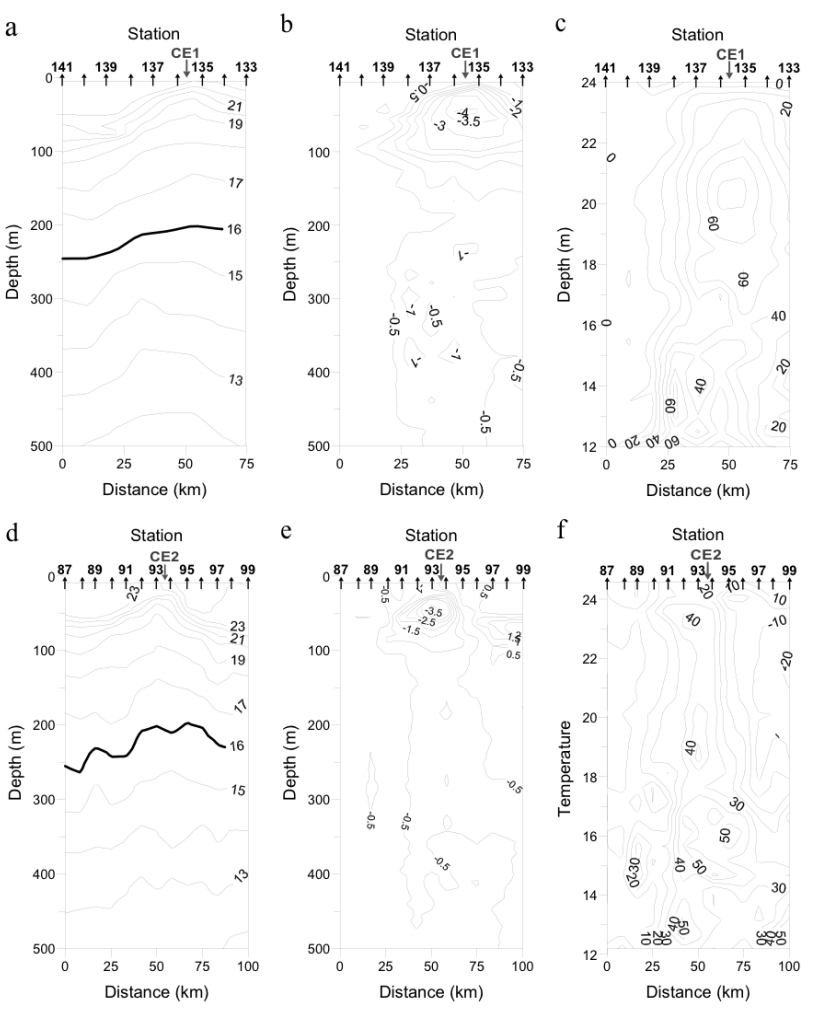

Fig. 2. Vertical sections from XBT transects showing the signals of cyclonic eddies CE1 and CE2. Left panels: temperature $\left({ }^{\circ} \mathrm{C}\right)$ section for (a) CE1 and (c) for CE2. Right panels: temperature anomaly $\left({ }^{\circ} \mathrm{C}\right)$ sections for (b) CE1 and (d) CE2. Grey arrow in the top axes indicates the location of the eddy center signal.

internalGraphik ist zu klein zu lesen, bitte groesser machen.

Samples for the quantification of nano- and microphytoplankton abundance were sampled at surface $(5 \mathrm{~m})$ and the deep chlorophyll maximum (DCM). Samples of 2-3 L were concentrated onto $50-70 \mathrm{~mL}$ samples by using a Millipore 
Table 1. Oceanographic properties characterizing the structure of cyclonic and anticyclonic eddies (CEs and AEs, respectively) studied. T. anomaly corresponds to the temperature anomaly.

\begin{tabular}{lllll}
\hline EDDY & CE1 & CE2 & AE1 & AE2 \\
\hline Origin & Gran Canaria & La Palma & El hierro & Gran Canaria \\
Eddy Type & Cyclonic & Cyclonic & Anticyclonic & Anticyclonic \\
Data type & CTD & XBT-CTD $(\mathrm{L})$ & XBT & XBT \\
T. anomaly & $-4^{\circ} \mathrm{C}(50 \mathrm{~m})$ & $-4.56^{\circ} \mathrm{C}(50 \mathrm{~m})$ & $3.5^{\circ} \mathrm{C}(140 \mathrm{~m})$ & $4.5^{\circ} \mathrm{C}(70 \mathrm{~m})$ \\
H. anomaly & $-77 \mathrm{~m}$ & $-64 \mathrm{~m}$ & $73 \mathrm{~m}$ & $65 \mathrm{~m}$ \\
Depth & $>500 \mathrm{~m}$ & $350 \mathrm{~m}$ & $350 \mathrm{~m}$ & $300 \mathrm{~m}$ \\
Mixing layer depth & $20 \mathrm{~m}$ & $30 \mathrm{~m}$ & $160 \mathrm{~m}$ & $90 \mathrm{~m}$ \\
\hline
\end{tabular}

cell concentrator chamber, which allows concentration of cells with no significant effect on cellular status (e.g. viability, movement for flagellated cells, integrity of frustules) (Agustí and Sánchez, 2002; Alonso-Laita and Agustí, 2006; Lasternas et al., 2010). Phytoplankton cells were counted using an epifluorescence microscope (Zeissé Axioplan Imaging) and were classified into 3 majors groups, nanoflagellates, dinoflagellates and diatoms, which were separated into pennate and centric.

Autotrophic picoplankton abundance was assessed using flow cytometry as described in Lasternas et al. (2010). At each station, duplicated $2 \mathrm{~mL}$ fresh samples from 5 depths were counted on board (duplicated counts) using a FACSCalibur flow cytometer (Beckton Dickinsoné). The red (FL3, bandpass filter $670 \mathrm{~nm}$ ), green (FL1 bandpass filter $530 \mathrm{~nm}$ ) and orange (FL2, bandpass filter $585 \mathrm{~nm}$ ) fluorescence, and forward- and side-scattering signals of the cells and beads were used to detect picoplanktonic populations of Synechococcus, Prochlorococcus and eukaryotes (Marie et al., 2005).

The proportion of dead cells in the autotrophic communities examined was quantified by applying a cell membrane permeability test, the cell digestion assay (CDA; Agustí and Sánchez, 2002). The CDA involves the exposure of phytoplankton cells to an enzymatic cocktail (DNAse and Trypsin) that enters the cytoplasm and digests cells with compromised membranes, the dead or dying cells, which are removed from the sample. The cells remaining in the samples after the CDA are the living cells, those with intact membranes, which were then counted by flow cytometry or epifluorescence microscope, as described above (cf. Agustí and Sánchez, 2002). The CDA was applied to the concentrates of nano- and microphytoplankton cells prepared to quantify total cell abundance and to fresh samples of picophytoplankton cells from the 5 same depths selected to estimate total picophytoplankton abundance at each station.

The cell digestion assay was applied to duplicate aliquots by adding first a DNAse I solution $\left(400 \mu \mathrm{g} \mathrm{mL} \mathrm{m}^{-1}\right.$ in HBSS (Hanks' Balanced Salts)) and, after 15 min incubation at $35^{\circ} \mathrm{C}$ in a digital dry bath, adding trypsin solution $(1 \%$ in HBSS). The treated samples were incubated for a further
$30 \mathrm{~min}$ at $35^{\circ} \mathrm{C}$ and finally placed in ice in order to cease enzymatic activity. Nano- and microphytoplankton treated samples were then filtered onto polycarbonate $2 \mu \mathrm{m}$-porediameter black filters, washed several times with filtered seawater, fixed with gluteraldehyde ( $1 \%$ final concentration) and stored frozen at $-80^{\circ} \mathrm{C}$ until counting by epifluorescence microscopy. Picophytoplankton-treated samples were counted by flow cytometry as described in Lasternas et al. (2010). The percentage of dead cells was calculated as the ratio between the concentration of dead cells (total concentration minus concentrations after applying the CDA, living cells) and total population abundance, which includes both living and dead cells (Agustí and Sánchez, 2002).

Primary production was assessed by the ${ }^{14} \mathrm{C}$ technique (Steeman-Nielsen, 1952). Seawater initially sampled at 5 depths, including the surface $(5 \mathrm{~m})$, two intermediate depths, the DCM and an ultimate depth below the DCM, was delivered into transparent (light) and black masking tapecovered polycarbonate bottles $(150 \mathrm{~mL})$, and inoculated with $80 \mu \mathrm{Ci}$ activity of a $\mathrm{NaH}^{14} \mathrm{CO}_{3}$ working solution. Depending on sea conditions, the incubations were deployed in a mooring buoy system and incubated in situ for $3 \mathrm{~h}$ at the same time of the day (from 12:00 to 16:00 LT), always including noon. Short-time incubations were used to minimize the contribution of trophic-related processes to DOC production (Morán and Estrada, 2002). For some of the stations, however, the deployment of the buoy was not possible and incubations, limited to 2 depths (surface and DCM), were performed on deck for $3 \mathrm{~h}$, using incubators at controlled temperature and adjusting the incident natural irradiance to that received in situ using neutral density screens. For each sample, two aliquots of $5 \mathrm{~mL}$ (replicates) were introduced in scintillation vials $(20 \mathrm{~mL})$ for the determination of total labeled organic carbon production (TPP); the sum of ${ }^{14} \mathrm{C}$ was incorporated into POC (particulate organic carbon) and released as DOC (dissolved organic carbon). After incubating over $24 \mathrm{~h}$ with scintillation cocktail (Packard Ultima Gold XR), disintegrations per minute from TPP and PPP vials were counted with a scintillation counter (EG\&G/Wallac). The $\mathrm{P}_{\mathrm{DOC}}$ by phytoplankton was calculated as the difference between total and particulate primary production, while the percentage of the extracellular 


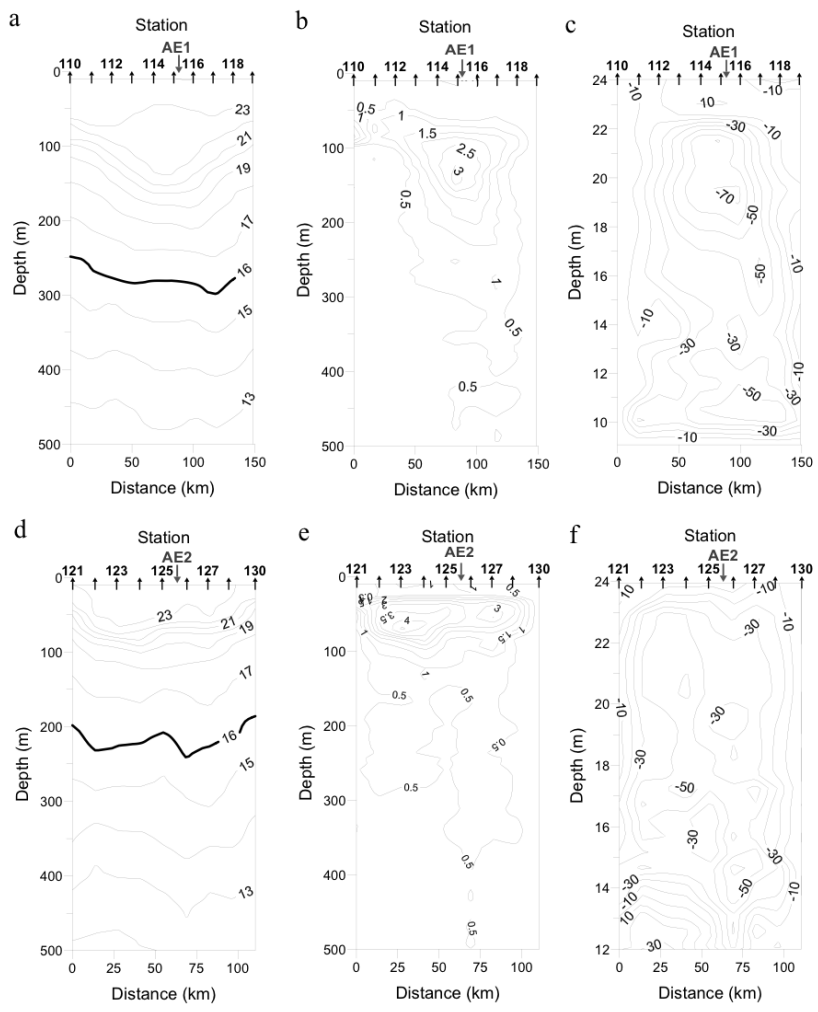

Fig. 3. Vertical sections from XBT transects showing the signals of anticyclonic eddies AE1 and AE2. Left panels, temperature $\left({ }^{\circ} \mathrm{C}\right)$ section for (a) AE1 and (c) for AE2. Right panels, temperature anomaly $\left({ }^{\circ} \mathrm{C}\right)$ sections for (b) AE1 and (d) AE2. Grey arrow in the top axes indicates the location of the eddy center signal.

internalGraphik ist zu klein zu lesen, bitte groesser machen.

production released by phytoplankton (PER) was calculated as $\left(\mathrm{P}_{\mathrm{DOC}} / \mathrm{TPP}\right) \times 100$.

Phytoplankton cell lysis rates were estimated using the dissolved esterase method as described in Agustí et al. (1998). Dissolved esterase activity (as fluorescein diacetate (FDA) hydrolysis) was measured in 3 replicates at 5 depths from the surface to the DCM. In short after sampling, $5 \mathrm{~mL}$ of water were filtered through $0.2 \mu \mathrm{m}$ Millipore Millex filters, and $50 \mu \mathrm{L}$ of EDTA and $50 \mu \mathrm{L}$ of FDA (Sigma Co.) were added to the samples (to a final concentration of 0.02 and $0.2 \mathrm{mM}$, respectively) and mixed in a vortex mixer. After incubating the samples for an hour at $20^{\circ} \mathrm{C}$, the fluorescence emission was immediately measured in a Shimadzu RF-5000 spectrofluorometer at $451 \mathrm{~nm}$ and $510 \mathrm{~nm}$ excitation and emission $(10 \mathrm{~nm}$ bandwidth) wavelengths, respectively. The particulate esterase activity (PEA), needed to estimate the lysis rate, was calculated from the measured chl $a$ concentration using a ratio of PEA to chl $a$ of $224.5 \pm 83.18$ (Mean \pm SE) nanoMol fluoresceine $\mathrm{h}^{-1} \mathrm{mg}^{-1} \mathrm{chl} a$, derived from the particulate esterase of phytoplankton cultures (Prochlorococcus marina, Synechococcus sp. (strain \#1), Synechococcus sp. (strain \#2), Chlorella marina, Phaeocystis sp., Heterocapsa sp., and Thalassiosira sp.) as described by Agustí and Duarte (2002). To avoid overestimation of the phytoplankton lysis rates in most oligotrophic waters where picophytoplankton dominated phytoplankton biomass, the PEA/chl $a$ ratio applied was $377 \pm 101.27$ (Mean \pm SE) nanoMol fluoresceine $\mathrm{h}^{-1} \mathrm{mg}^{-1} \mathrm{chl} a$, derived from the PEA of picophytoplanktonic cultures (Prochlorococcus marina, Synechococcus sp. (strain \#1), Synechococcus sp. (strain \#2), and, Chlorella marina).

At each station, the abundance and the proportion of living heterotrophic bacteria were quantified in samples collected at 5 depths. As performed in Lasternas et al. (2010), the nucleic acid double staining (NADS) protocol (Gregori et al., 2001), involving the use of two nucleic acid fluorescent dyes, SYBR Green I (SG1; Molecular Probes) and propidium iodide (PI; Sigma Chemical Co.), was used. Bacterial membranes are permeable to SG1, whatever the cell viability, resulting in green fluorescence when stained. However, living or viable cells with intact plasmic membranes are impermeable to PI. Thus, only compromised or damaged cells are stained with PI (Barbesti et al., 2000), showing red fluorescence as described in Falcioni et al. (2008). Bivariate plots of green versus red fluorescence (FL1 vs. FL3) on cytometer allowed discriminating live (green fluorescent, impermeable to PI) from dead cells (red fluorescent membrane-compromised cells, stained by PI and SG1). Total heterotrophic bacterial abundance, in cells $\mathrm{mL}^{-1}$, was calculated as the sum of red and green fluorescent cell abundance, while living bacterial cell abundance was determined from the green fluorescent cell counts.

\subsection{Data analysis}

Spearman's rank coefficients $\left(r_{\mathrm{s}}\right)$ were used to determine the correlation between variables that departed from normality (Siegel and Castellan, 1988). Statistical significance of the differences between average values was tested using Student's $t$ test, with a critical $p$ value of 0.05 .

\section{Results}

\subsection{Hydrophysical eddy structures}

Three contrasting zones were characterized during the cruise, the cyclonic and anticyclonic oceanic eddy (CE and $\mathrm{AE}$ ) fields located at the lee of the Canary Islands and the far-field off the archipelago. Far-field stations were away from the influence of the islands, so probably undisturbed by any eddy (Fig. 1). The depth of the eddies sampled, obtained from the temperature anomaly sections (Figs. 2 and 3), ranged between 300 for AE2 and greater than $500 \mathrm{~m}$ for CE1 (Table 1). Cyclones of La Palma (CE2) and Gran Canaria (CE1) were close to the southwest flank of these islands (Fig. 1) and were sampled at their early life stage (spin-up stage), having a radius of about $25 \mathrm{~km}$ and about $35 \mathrm{~km}$, respectively. Their signal on the SST was observed approximately 5 days 

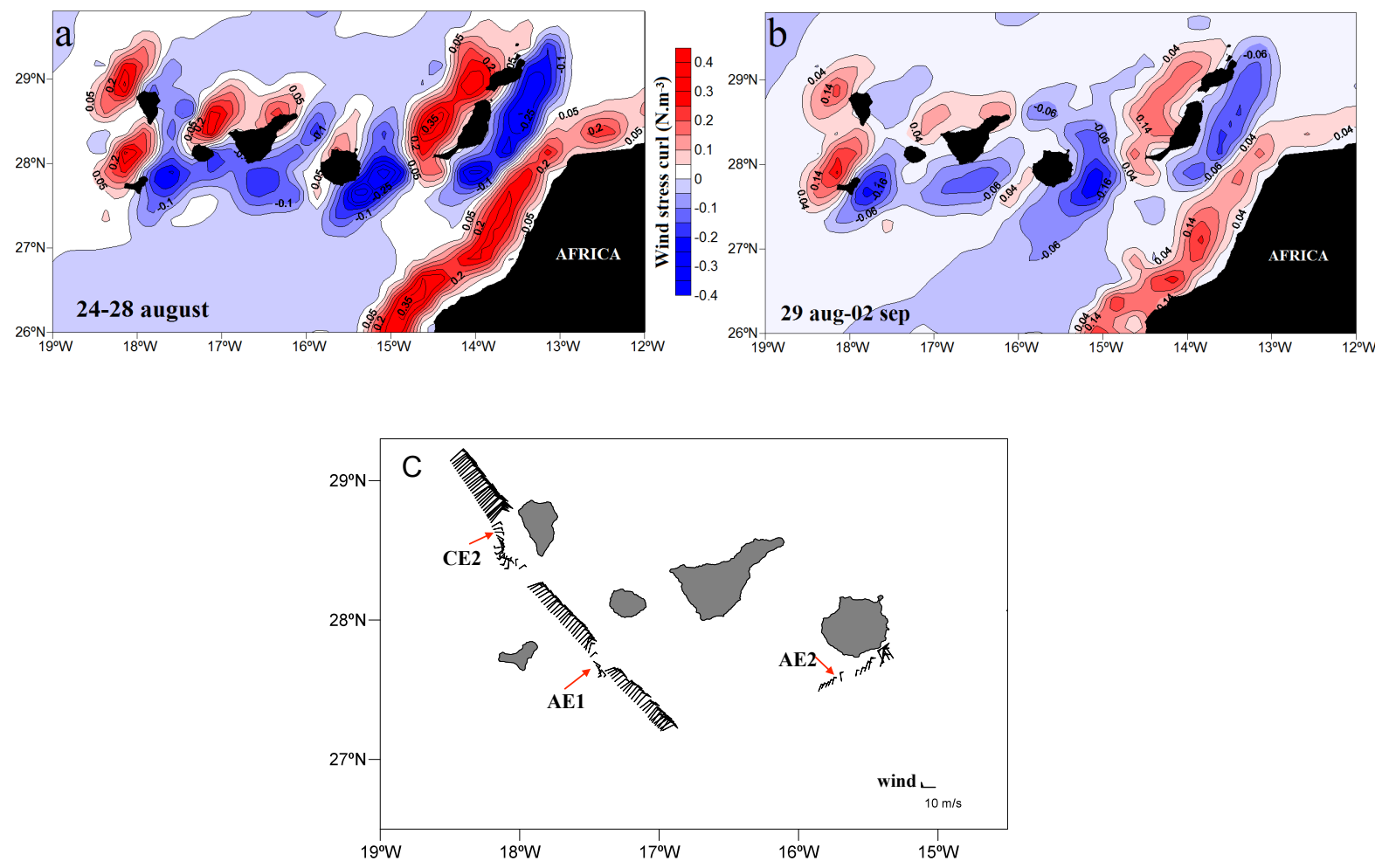

Fig. 4. Five-day-averaged wind curl (a), (b) and instantaneous wind field from the onboard meteorological station (c).

(CE2) and 7 days (CE1) before the sampling, indicating that they are at least one week older. Anticyclone AE1, probably generated by the island of Tenerife but located far from this island at the time of sampling and hence relatively older, presented the larger observed radius of about $65 \mathrm{~km}$. We may give an estimate of the eddy age considering that previous observations (Sangrà et al., 2005) indicate a spin-up time (half of the Strouhal frequency) of one week and once detached a mean advection velocity of ca. $4 \mathrm{~km} \mathrm{day}^{-1}$. If originated by Tenerife this will result in an age of ca. 4 weeks. The Gran Canaria anticyclone, AE2, with a smaller radius of about $50 \mathrm{~km}$, was located close to the island of origin and therefore was younger than AE1, being at its early stage of generation (spin-up stage) and having an estimated age from its SST signal of at least of 7 days. The cyclones' signatures were apparent on the temperature sections through the doming of the isotherms introducing negative temperature anomalies in the water column (Fig. 2). The maxima of the temperature anomaly helped us locate the center of the eddies, which was then selected for biogeochemical sampling (stations CE1CE2 in Fig. 2). Negative temperature anomalies introduced by these cyclones were rather large, being approximately $4{ }^{\circ} \mathrm{C}$ (Table 1) at $50 \mathrm{~m}$ depth. The base of the seasonal thermocline was marked by the $20^{\circ} \mathrm{C}$ isotherm (Fig. 2a and c), and its depth just outside the eddies was around $100 \mathrm{~m}$ shoaling at the eddy centers until $30 \mathrm{~m}$ for CE1 and $50 \mathrm{~m}$ for CE2.
Anticyclones deepened the isotherms, introducing positive anomalies in the temperature field (Fig. $3 b$ and d). As in the case of cyclones, the maxima of the temperature anomaly helped us to locate the eddy center. The eddy center of AE1 was well defined by these maxima, which was then selected for biogeochemical sampling for AE1 (Fig. 3b). The vertical section crossing AE2 does not show a well-defined eddy center; however, temperature anomalies (Fig. 3d) suggested that sampling was not far from the eddy center (Table 1). The $20^{\circ} \mathrm{C}$ isotherm deepened $50 \mathrm{~m}$ from the eddy periphery to the center in the case of AE1 and $40 \mathrm{~m}$ in the case of AE2. In the case of the Canary anticyclones, it has been observed that the nutricline deepens accompanying the isopycnal/isotherms.

Mean wind curl obtained from CCMP climatology showed that cyclonic/anticyclonic wind curl cells affected the sampled eddies (Fig. 4a and b). According to this, instantaneous wind data recorded along the eddy transects showed also the occurrence of strong wind shears/wind curls (Fig. 4c). CCMP data were five day averages and must be taken with some caution because their resolution $\left(0.25^{\circ}\right)$ merely resolved the wind curl cells. Therefore, a certain divergence may be expected when comparing the location of the maximum instantaneous wind shear/curl from ship observations and from CCMP as in the case for La Palma.

Figure 4 shows a strong wind shear along CE2 (Fig. 4c) related with the relatively strong cyclonic wind curl cell of La Palma (Fig. 4a and b). The maximum cyclonic wind 
Table 2. Average $\pm \mathrm{SE}$ and range of variability of nutrients concentration, temperature, chlorophyll $a$, primary production (total and particulate) and lysis rates observed in the water column of the cyclonic and anticyclonic eddies and far-field stations studied. Average values for systems connected by different letters $(\mathrm{a}, \mathrm{b})$ are significantly different $(p<0.05)$.

\begin{tabular}{|c|c|c|c|}
\hline Variable & Anticyclonic eddies & Cyclonic eddies & Far-fields \\
\hline $\mathrm{DIP}(\mu \mathrm{M})$ & $\begin{array}{l}0.05 \pm 0.03^{b} \\
(0.001-0.25)\end{array}$ & $\begin{array}{r}0.29 \pm 0.03^{\mathrm{a}} \\
(0.08-0.36)\end{array}$ & $\begin{array}{l}0.001 \pm 0.00^{b} \\
(0.001-0.001)\end{array}$ \\
\hline Silicate $(\mu \mathrm{M})$ & $\begin{array}{r}0.44 \pm 0.04^{b} \\
(0.23-0.58)\end{array}$ & $\begin{array}{r}0.69 \pm 0.12^{\mathrm{a}} \\
(0.21-1.27)\end{array}$ & $\begin{array}{r}0.69 \pm 0.03^{\mathrm{a}} \\
(0.55-0.83)\end{array}$ \\
\hline $\mathrm{DIN}(\mu \mathrm{M})$ & $\begin{array}{r}0.26 \pm 0.12^{\mathrm{b}} \\
(0.04-0.85)\end{array}$ & $\begin{array}{r}1.21 \pm 0.47^{\mathrm{a}} \\
(0.08-3.97)\end{array}$ & $\begin{array}{r}0.14 \pm 0.05^{b} \\
(0.06-0.49)\end{array}$ \\
\hline Ammonium $(\mu \mathrm{M})$ & $\begin{array}{r}1.26 \pm 0.21^{\mathrm{a}} \\
(0.36-2.18)\end{array}$ & $\begin{array}{r}0.28 \pm 0.04^{\mathrm{b}} \\
(0.18-0.41)\end{array}$ & $\begin{array}{r}0.72 \pm 0.15^{b} \\
(0.09-1.33)\end{array}$ \\
\hline Temperature $\left({ }^{\circ} \mathrm{C}\right)$ & $\begin{array}{l}22.4 \pm 0.5^{\mathrm{a}} \\
(19.6-24.0)\end{array}$ & $\begin{array}{l}19.8 \pm 0.8^{b} \\
(17.3-23.1)\end{array}$ & $\begin{array}{l}21.9 \pm 0.8^{\mathrm{a}} \\
(18.5-24.8)\end{array}$ \\
\hline $\begin{array}{l}\text { Chlorophyll } a \\
\left(\mathrm{mg} \operatorname{chl} a \mathrm{~m}^{-3}\right)\end{array}$ & $\begin{array}{r}0.26 \pm 0.05^{\mathrm{b}} \\
(0.07-0.49)\end{array}$ & $\begin{array}{r}0.52 \pm 0.13^{\mathrm{a}} \\
(0.13-1.38)\end{array}$ & $\begin{array}{r}0.25 \pm 0.06^{\mathrm{b}} \\
(0.11-0.72)\end{array}$ \\
\hline $\begin{array}{l}\text { Total Primary Production } \\
\left(\mathrm{mg} \mathrm{C} \mathrm{m}^{-3} \mathrm{~h}^{-1}\right)\end{array}$ & $\begin{array}{r}0.332 \pm 0.007^{\mathrm{a}} \\
(0.15-0.49)\end{array}$ & $\begin{array}{r}0.142 \pm 0.005^{\mathrm{b}} \\
(0.04-0.26)\end{array}$ & $\begin{array}{r}0.135 \pm 0.003^{b} \\
(0.08-0.23)\end{array}$ \\
\hline $\begin{array}{l}\text { Particulate Primary Production } \\
\left(\mathrm{mg} \mathrm{C}^{-3} \mathrm{~h}^{-1}\right)\end{array}$ & $\begin{array}{r}0.100 \pm 0.007^{\mathrm{a}} \\
(0.01-0.31)\end{array}$ & $\begin{array}{r}0.062 \pm 0.028^{\mathrm{a}} \\
(0.01-0.14)\end{array}$ & $\begin{array}{r}0.042 \pm 0.004^{\mathrm{a}} \\
(0.03-0.05)\end{array}$ \\
\hline Lysis rates $\left(\mathrm{d}^{-1}\right)$ & $\begin{array}{r}0.86 \pm 0.23^{\mathrm{a}} \\
(0.31-2.75)\end{array}$ & $\begin{array}{r}0.47 \pm 0.08^{\mathrm{a}, \mathrm{b}} \\
(0.15-0.84)\end{array}$ & $\begin{array}{r}0.42 \pm 0.06^{b} \\
(0.11-0.66)\end{array}$ \\
\hline
\end{tabular}

shear/curl was located near the eddy center (Fig. 4c). A close inspection of Fig. 2d showed a surface outcropping of those isotherms located at the base of the mixed layer, probably corresponding to water upwelling at the eddy center by the upward Ekman pumping vertical velocity linked with the cyclonic wind curl cell. Although there were no reliable shipboard wind observations for eddy CE1, Fig. 4a and b show a small cyclonic wind curl cell at the eddy location. Therefore, as in the case of eddy CE2, we encountered favorable conditions for upwelling (upward Ekman velocity), as related to the divergence of the Ekman transport. For the case of eddies AE1 and AE2, averaged CCMP data showed a strong wind curl anticyclonic cell at the eddies' locations (Fig. 4a and b). Instantaneous ship observations indicated that maximum wind shears/curl were located near the eddies' centers (Fig. 4c). The occurrence of a strong anticyclonic wind curl/shear indicated that favorable conditions for downwelling (downward Ekman pumping velocity) related to the convergence of the Ekman transport were present.

\subsection{Biogeochemical characteristics/properties}

Nutrient concentrations were significantly higher at cyclonic than at anticyclonic eddies (Student's $t$ test, $p<0.05$; Table 2). Silicate concentration at FF stations was similar to that at $\mathrm{CE}$ and higher than that at $\mathrm{AE}$ stations. Concentrations of other nutrient species were significantly lower at FF than at CE stations (Table 2). DIN concentrations were similar at $\mathrm{AE}$ and FF stations, while DIP concentrations were very low at FF stations. Ammonium concentrations were higher at $\mathrm{AE}$ stations than those at $\mathrm{FF}$ and $\mathrm{CE}$ stations. Water temperature in the CEs was lower on average (Student's $t$ test, $p<0.05$; Table 2) than that in the other systems. FF presented a wider gradient of temperature but did not differ significantly from AE stations (Table 2).

Chlorophyll $a$ concentrations presented similar vertical profiles among the two CEs and the two AEs (Fig. 5). Averaged chlorophyll $a$ by eddies (CE vs. AE) displayed significantly higher concentration in cyclonic than in anticyclonic systems (Table 2), but were similar in the AEs and FFs. The DCM was significantly shallower $(43.6 \pm 0.6 \mathrm{~m})$ at CE (Student's $t$ test, $p<0.05)$ than at AE $(75.5 \pm 1.2 \mathrm{~m})$ and FF stations $(70 \pm 1.3 \mathrm{~m})$. The chlorophyll $a$ concentration was positively related to the total phytoplankton biomass, as biovolume $\left(r_{\mathrm{s}}=0.36, p<0.05\right.$, $\left.\mathrm{df}=12\right)$, in the study. In the AEs, chlorophyll $a$ was positively related to picophytoplankton biovolume $\left(r_{\mathrm{s}}=0.63, p<0.05\right.$, $\mathrm{df}=12$ ), while in the cyclonic eddies it was associated with microphytoplankton biovolume. The picophytoplankton fraction dominated autotroph communities during the study, showing the higher abundances in the AEs (Fig. 6a). There were no significant differences in the abundance of picophytoplankton groups within the two CEs and the two AEs (Student's $t$ test, $p<0.05$ ). Prochlorococcus sp. dominated and was significantly more abundant in the AEs $\left(2.2 \pm 0.4 \times 10^{5}\right.$ cells $\left.\mathrm{mL}^{-1}\right)$. Synechococcus sp. presented maximum values in the CEs $\left(6.7 \pm 1.9 \times 10^{3}\right.$ cells $\left.\mathrm{mL}^{-1}\right)$, although the average abundance did not differ significantly between zones. Picoeukaryotes showed contrasting abundance 


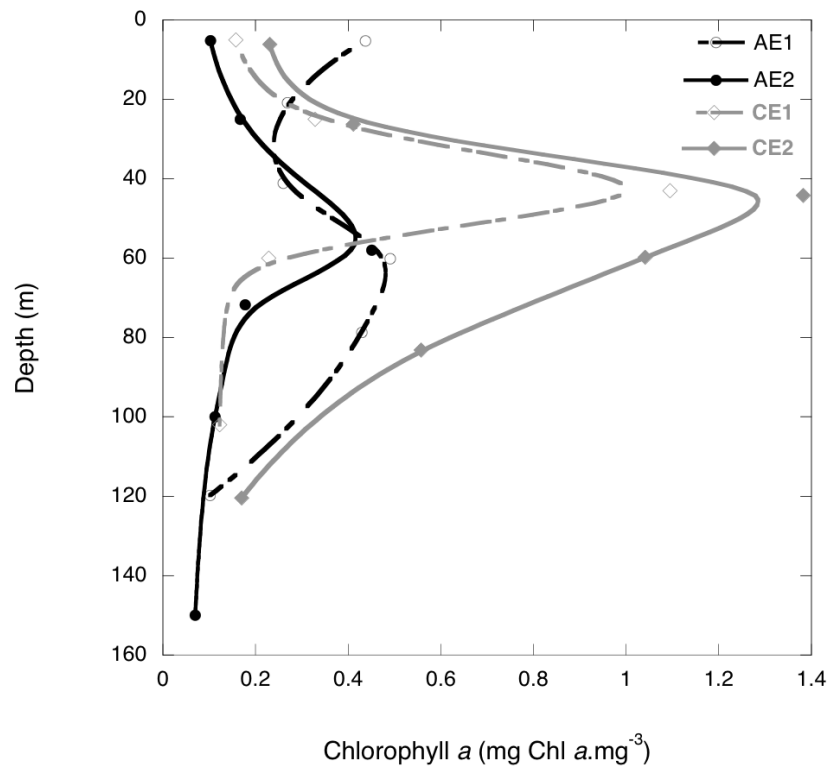

Fig. 5. Chlorophyll $a$ depth profiles at the two anticyclonic eddies (AE1 and AE2) and at the two cyclonic eddies (CE1 and CE2).

distributions, with higher averaged abundance at $\mathrm{CE}$ than at the AE and FF stations.

The microphytoplankton fraction displayed a contrasting pattern with that observed for picophytoplankton. Averaged microphytoplankton abundances were low at FF stations, increasing at $\mathrm{AE}$ and significantly higher at $\mathrm{CE}$ stations (Fig. 6b). Nanoflagellates followed a similar trend (Table 3). Diatom abundances were significantly higher in the CE zone than in the other two systems (Table 3), while dinoflagellates presented similar abundances between the $\mathrm{AE}$ and $\mathrm{FF}$ stations (Table 3 ). We also observed contrasting vertical distribution between diatoms and nanoflagellates, with diatoms (mostly centric) prevailing at the surface in the AEs and at DCM layers in the CEs, while nanoflagellates presented an opposite distribution.

Diatoms showed higher averaged \% DC in the AEs, and lowest in the cyclonic eddies (Fig. 7b), with nano- and microphytoplankton cells showing a higher proportion of dead cells in the AEs and low percentages of dead cells in the CEs (Fig. 7a). The percent of dead picophytoplankton cells ranged broadly, from 16 to $62.3 \%$ of dead cells among communities in the study, and showed also differences between the eddy systems studied, being significantly higher inside the anticyclonic eddy systems (Fig. 7c). Prochlorococcus sp. presented the lowest percentage of dead cells at the FF stations ( $42.2 \pm 3.4 \%$ DC), while Synechococcus sp. and picoeukaryotes displayed the lowest $\%$ DC values in the CE system (17.9 $\pm 6.8 \%$ DC and $25.8 \pm 6.1 \%$ DC, respectively).

While particulate primary production (PPP) rates presented low variation (averaging $0.062 \pm 0.024 \mathrm{mg} \mathrm{C} \mathrm{m}^{-3} \mathrm{~h}^{-1}$ ), with no significant dif- ferences between zones (Table 2; Student's $t$ test, $p<0.05$ ), we observe higher total primary production (particulate plus dissolved) in the AEs (Table 2). This was mostly due to the high production of dissolved organic carbon at this zone. Indeed, $P_{\mathrm{DOC}}$ presented significantly higher rates in the AEs and subsequently higher PER (the percentage of TPP excreted as $\mathrm{P}_{\mathrm{DOC}}$ ), than at the others areas (Table 2). The percentage of extracellular release by phytoplankton averaged $69.5 \pm 6.5 \%$ and ranged from 31 to $98 \%$ throughout the study, with higher averages found in the AEs $(70.3 \pm 7.7 \%)$. Moreover, phytoplankton cell lysis rates reached also maximum rates in the AEs (Table 2), while we observed similar lower values at $\mathrm{CE}$ and FF stations. The high lysis rates measured in the AEs (Table 2) were consistent with the high percentage of dead nano- and microphytoplankton cells $\left(r_{\mathrm{s}}=0.76, p<0.05\right)$ at these waters where we observed also the highest $\mathrm{P}_{\mathrm{DOC}}$ by phytoplankton at these stations (Table 2), as indicated by the significant positive relationship between $\mathrm{P}_{\mathrm{DOC}}$ concentration and lysis rates $\left(R^{2}=0.76, p<0.0005\right.$; Fig. 8$)$. Moreover, we also found a moderate but significant relationship between PER and lysis rates (PER vs log lysis, $R^{2}=0.38, p<0.03$ ), which also supported a higher excretion of $\mathrm{P}_{\mathrm{DOC}}$ associated with high lysis rates. HB abundance (Fig. 9a) was positively related to $\mathrm{P}_{\mathrm{DOC}}$ variation $\left(r_{\mathrm{s}}=0.65, p<0.05\right)$ and was significantly higher at $\mathrm{AE}$ and lower at the FF stations (Fig. 9a). Moreover, HB abundance was significantly associated with $\mathrm{NH} 4$ concentration throughout the study $\left(r_{\mathrm{s}}=\right.$ $0.59, p=0.0069$ ), and we observed a positive relationship between the percentage of living bacterial cells and $\mathrm{NH}_{4}$ concentration at $\mathrm{AE}$ stations $\left(R^{2}=0.96, p<0.005, \mathrm{df}=5\right)$. Bacterial viability, however, presented similar averages of $\%$ LC between anticyclonic and cyclonic eddies and was higher at FF stations (Fig. 9b). Moreover, HB viability was positively related to the percent of dead Synechococcus sp. cells $\left(R^{2}=0.53, p<0.001, \mathrm{df}=22\right)$.

\section{Discussion}

It has been suggested that the counter-paired cyclonic and anticyclonic eddies generated by the Canary Current and trade wind perturbation by the Canary Islands influence biological processes in the NE Atlantic region (Arístegui et al., 1997; Arístegui and Montero, 2005; González-Dávila et al., 2006; Sangrà et al., 2009). Our study aimed to comprehend the influence of anticyclonic/cyclonic eddies on biological processes including the cell physiological responses to the environmental changes associated with the anticyclonic/cyclonic eddies that may influence the path of the carbon photosynthesized by phytoplankton in the system. Our results indicated that the differences in environmental conditions (especially nutrient availability) associated with the upward/downward forcing of these anticyclonic/cyclonic eddies influenced phytoplankton cell physiology and generated differences in cell 
Table 3. Abundance of the microphytoplankton groups (average \pm SE, from the surface and DCM) in the cyclonic and anticyclonic eddies (CE and AEs, respectively) and far-field stations studied. Average values for systems connected by different letters (a, b) are significantly different $(p<0.05)$.

\begin{tabular}{lrrr}
\hline Average \pm SE $\left(\right.$ cells L $\left.^{-1}\right)$ & & & \\
Surface & Anticyclonic eddies & Cyclonic eddies & Far-fields \\
DCM & & & \\
\hline Nano- and microphytoplankton & $3.3 \pm 0.1 \times 10^{3} \mathrm{~b}$ & $6.4 \pm 1.2 \times 10^{3 \mathrm{a}}$ & $1.5 \pm 0.3 \times 10^{3 \mathrm{~b}}$ \\
$\quad$ Surface & $3.3 \pm 0.2 \times 10^{3}$ & $6.5 \pm 2.8 \times 10^{3}$ & $1.3 \pm 0.3 \times 10^{3}$ \\
DCM & $3.2 \pm 0.1 \times 10^{3}$ & $6.3 \pm 1.1 \times 10^{3}$ & $1.6 \pm 0.7 \times 10^{3}$ \\
\hline Nanoflagellates & $1.6 \pm 0.5 \times 10^{3 \mathrm{a}, \mathrm{b}}$ & $2.3 \pm 0.6 \times 10^{3 \mathrm{a}}$ & $6.6 \pm 0.2 \times 10^{2} \mathrm{~b}$ \\
Surface & $2.0 \pm 0.8 \times 10^{3}$ & $1.5 \pm 0.7 \times 10^{3}$ & $5.9 \pm 2.3 \times 10^{2}$ \\
DCM & $1.2 \pm 0.7 \times 10^{3}$ & $3.1 \pm 0.7 \times 10^{3}$ & $7.3 \pm 2.6 \times 10^{2}$ \\
\hline Diatoms & $6.4 \pm 1.8 \times 10^{2} \mathrm{a}, \mathrm{b}$ & $1.3 \pm 0.5 \times 10^{3 \mathrm{a}}$ & $1.8 \pm 0.4 \times 10^{2} \mathrm{~b}$ \\
Surface & $4.7 \pm 2.6 \times 10^{2}$ & $1.8 \pm 0.8 \times 10^{3}$ & $1.5 \pm 0.02 \times 10^{2}$ \\
DCM & $8.1 \pm 2.3 \times 10^{2}$ & $7.5 \pm 2.6 \times 10^{2}$ & $2.2 \pm 0.9 \times 10^{2}$ \\
\hline Dinoflagellates & $2.0 \pm 0.3 \times 10^{2} \mathrm{~b}$ & $7.6 \pm 1.1 \times 10^{2} \mathrm{a}$ & $2.2 \pm 0.6 \times 10^{2} \mathrm{~b}$ \\
Surface & $1.9 \pm 0.6 \times 10^{2}$ & $6.6 \pm 2.4 \times 10^{2}$ & $2.1 \pm 0.5 \times 10^{2}$ \\
DCM & $2.1 \pm 0.4 \times 10^{2}$ & $8.5 \pm 0.5 \times 10^{2}$ & $2.4 \pm 1.4 \times 10^{2}$ \\
\hline
\end{tabular}
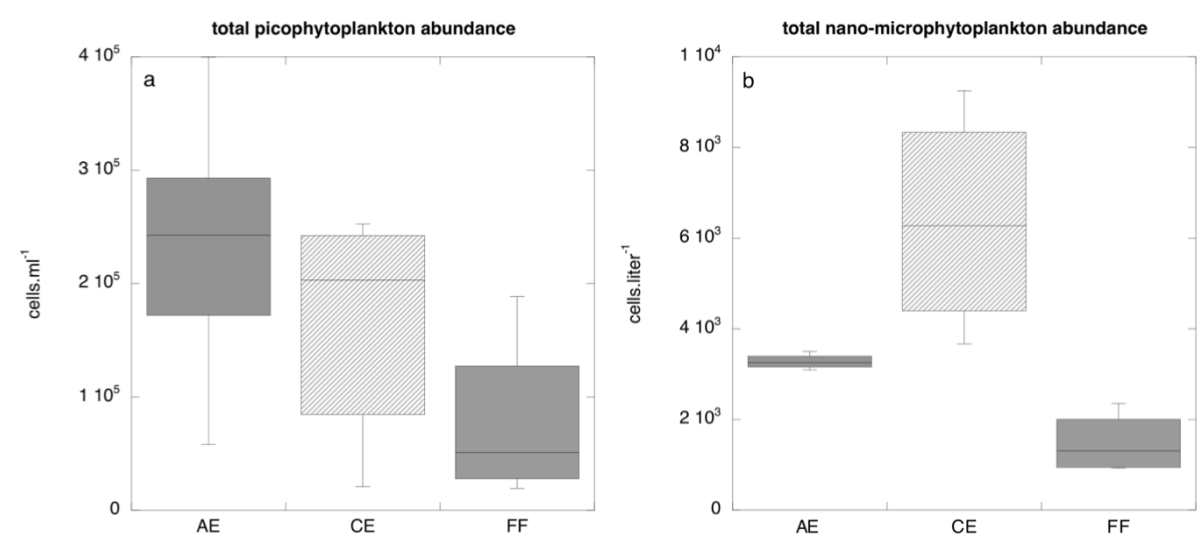

Fig. 6. Distribution of the total pico- (a) and nano- and microphytoplankton (b) within AE, CE and FF stations. Boxes show the lower and upper quartiles, median, minimum and maximum values.

stress and death that forced the carbon dynamics by increasing the excretion of primary production as DOC in the $\mathrm{AE}$ systems. Our analysis of phytoplankton cell death processes within the eddy systems revealed important differences, with phytoplankton populations experiencing higher cell mortality and cell lysis at the anticyclonic eddies.

\subsection{Cyclonic eddies}

Cyclonic features described during our study supported higher phytoplankton biomass as they enhanced nutrient inputs to the surface, resulting in increased nutrient concentrations and higher chlorophyll $a$ concentrations than reported for other cyclonic systems (McGillicuddy et al., 1998; Oschlies and Garçon, 1998; Siegel et al., 1999; Tarran et al.,
2001). The increase in nutrients observed at the center of cyclonic eddies and the corresponding enhancement of phytoplankton abundance detected (as in Rodríguez et al., 2003) in the center of these mesoscale features may be attributed to both the shoaling of the nutricline and to an upward diapycnal flow (upwelling). The cyclonic wind curl/shear cell that interacts with CEs may cause a divergence of the Ekman transport that leads to an upward Ekman pumping velocity (Jiménez et al., 2008) and hence to favorable upwelling conditions. At this spin-up stage not only a shoaling of the isotherms may be expected at the eddy center but also an uplifting of said isotherms that may originate upwelling. Enhancement of chlorophyll $a$ has been recurrently observed at the western flanks of the Canary Island in color satellite 

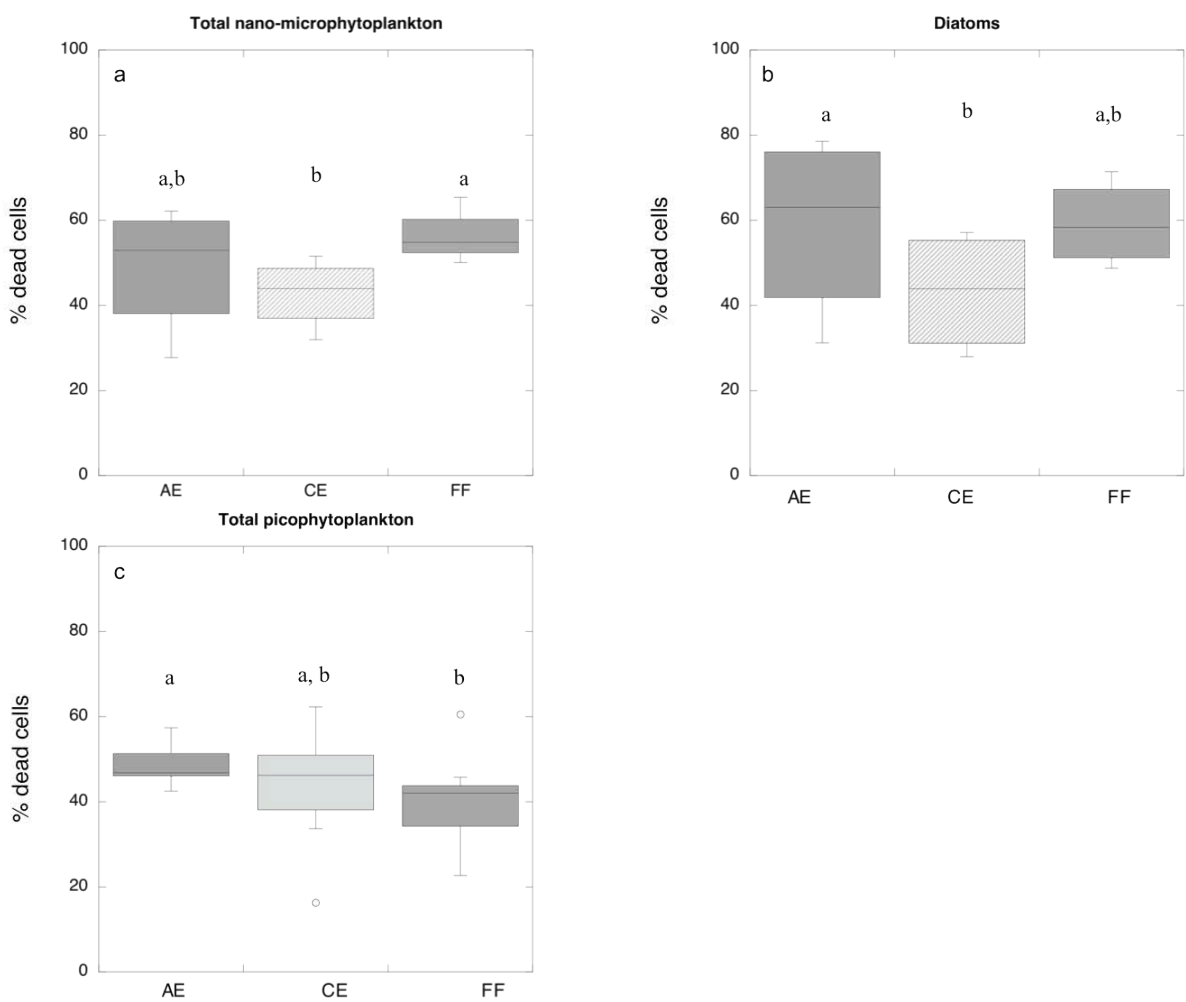

Fig. 7. Distribution of the viability (percentage of living cells) of (a) total nano- and microphytoplankton, (b) diatoms and (c) total picoplankton populations within $\mathrm{AE}, \mathrm{CE}$ and FF stations. Boxes show the lower and upper quartiles, median, minimum and maximum values, and outliers (open circles). Boxes connected by same letter are not significantly different $(p<0.05)$.

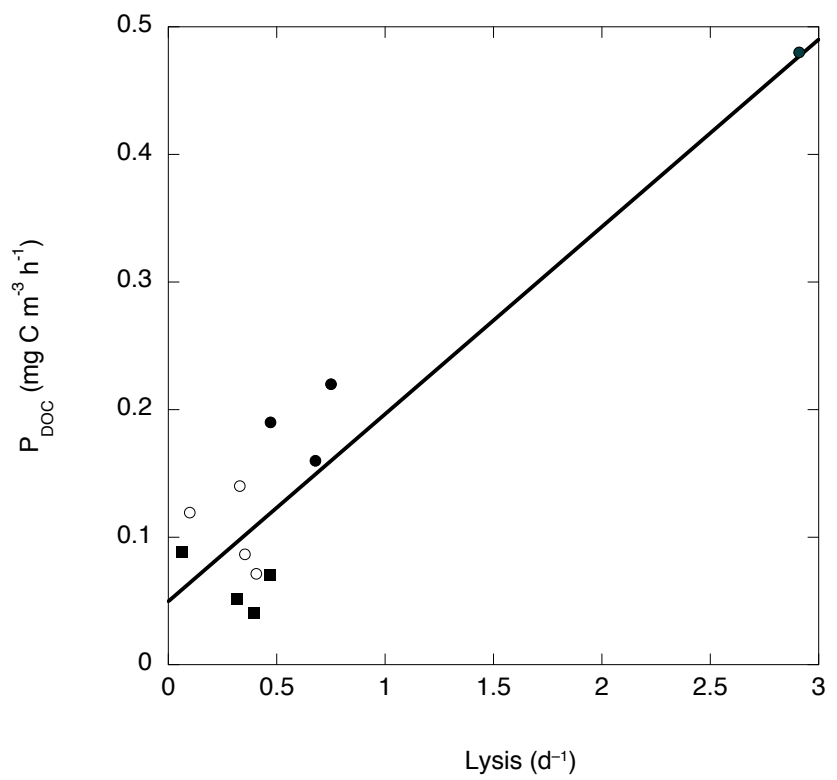

Fig. 8. The relationship found between dissolved organic carbon production by phytoplankton and lysis rates $\left(R^{2}=0.76\right.$, $p<0.0005$ ). Data from AE (full circles), CE (open circles) and FF (full squares) stations. images coinciding with the strong wind curl cells occurring at the generation of CEs (Sangrà et al., 2009).

Besides the enhancement of phytoplankton biomass in the CEs, the results presented here provide evidence that eddies' features also control the community structure and cell status of phytoplankton, as indicated by a significant increase in nano- and microphytoplankton abundance at CE waters, especially diatoms, and a decline in the abundance of picophytoplankton. At the cyclonic eddies, the higher diatom abundance and similar availability of $\mathrm{Si}$ in comparison with the far-field stations suggest that phytoplankton has already used the nutrient. The low cell mortality (lower \% of dead cells) of diatoms in CE systems suggested that they are probably not yet in a post-bloom phase, although phytoplankton lysis rates were similar to those shown at FF stations, most probably due to the higher cell death in the CEs of picophytoplankton, which showed a higher proportion of dying cells. Rodríguez et al. (2003) observed that upward velocities favor the growth of large phytoplankton cells. Here in our study, we found a higher microphytoplankton proportion of living cells and lower lysis rates at the upward conditions in the cyclonic stations in agreement with more-favorable conditions to increase the proportion of larger phytoplankton cells. Therefore the significant increase in diatoms we observed in the CEs is likely to be related with upward velocity and 

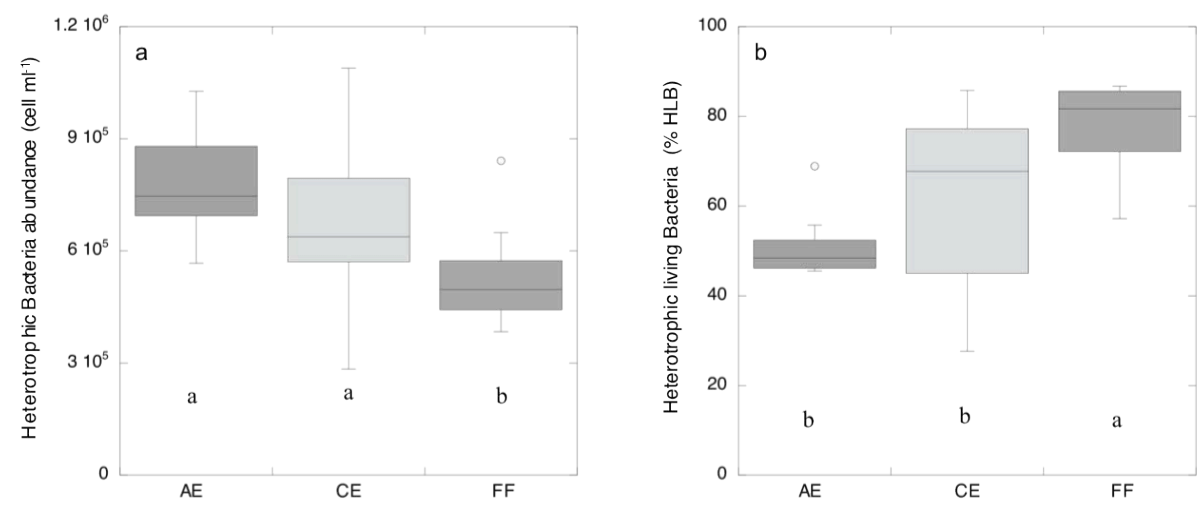

Fig. 9. Distribution of (a) the abundance and (b) viability (percentage of living cells) of the heterotrophic bacteria within AE, CE and FF stations. Boxes show the lower and upper quartiles, median, minimum and maximum values, and outliers (open circles). Boxes connected by same letter are not significantly different $(p<0.05)$.

upwelling dynamics at the center of those structures. Vaillancourt et al. (2003) also observed an increase of microphytoplankton at a cyclonic eddy attached to the northwestern flank of the island of Hawaii, similar to our observations. Jia et al. (2011) recently reported the occurrence of a strong cyclonic wind curl cell, associated with favorable upwelling conditions at the Hawaiian Islands. The favorable conditions for the development of a phytoplankton community dominated by large phytoplankton cells in cyclonic eddies may enhance the primary production efficiency with potentially larger carbon sequestration associated with these structures.

\subsection{Anticyclonic eddies}

In contrast to cyclonic eddies, we observed lower nutrient availability in anticyclonic eddies related with the deepening of the nutricline and with a downward diapycnal flow. Indeed, our results documented the occurrence of anticyclonic wind curl/shear regions partly responsible for the eddies' generation (Jiménez et. al., 2008; Piedeleu et al., 2009) in the Canary Eddy Corridor, favoring downward Ekman pumping velocities (Jiménez et al., 2008) and downward fluxes (downwelling) as previously described (Basterretxea et al., 2002). Originally located at the vicinity of the productive Gran Canaria current, anticyclonic eddies sampled in this study were at their early stage characterized by particularly active downward processes, progressively depleting the system of nutrients and influencing biological processes at the upper layers. Indeed, the reduction in nutrient availability may favor the predominance of picoplanktonic forms better adapted to oligotrophic conditions (Platt et al., 1983; Agawin et al., 2000; Lasternas et al., 2010), as reflected in the dominance of Prochlorococcus sp. The AE stations also presented higher bacterial abundance, as reported in parallel studies conducted at the same region (Baltar et al., 2010; Boras et al., 2010).

The setting-up of anticyclonic eddies altered the system as indicated by higher mortality of the nano- and microphytoplankton population at surface layers, despite compara- ble abundances to CE stations. Indeed, although we reported here higher nano- and microphytoplankton biomass at $\mathrm{AE}$ than FF stations, the percentage of dead cells was higher at the anticyclonic eddies and indicative of senescence of the populations induced by the downwelling processes in the AEs studied. The high variability of the nano- and microphytoplankton mortality values in the water column observed in the AEs illustrates the system alteration affecting the phytoplankton communities that are in transit from a dominance of nano- and microphytoplankton to that of picophytoplankton community, as indicated by the high fraction of dead diatom cells in the community. Diatoms have high nutrient requirements and are strongly impacted by nutrient depletion, particularly that of silicate (Martin-Jézéquel et al., 2000), a nutrient that clearly decreased in the $\mathrm{AE}$ compared to the $\mathrm{CE}$ and FF stations. Dinoflagellates, which typically thrive in stratified water conditions (Smayda and Reynolds, 2001), presented high mortality in the AEs (>70\% of dead cells), further suggesting that the strongly oligotrophic conditions together with downwelling and active mixing conditions in this zone offer conditions unsuitable for microphytoplankton. The picophytoplankton component showed lower cell mortality than nanomicroplankton but was also affected, as the proportion of dead cells was higher at AE stations than at far-field stations, which represent a likely "stable" environment for picophytoplankton groups where ecological niches are well defined (Agustí, 2004). The stressful conditions for autotrophs were reflected in high lysis rates at $\mathrm{AE}$ stations. Previous studies have presented similar lysis rates in the area (Agustí et al., 2001), likely associated with oligotrophic conditions, but the eddy systems generated variation in those rates as well. In our study, at the $\mathrm{AE}$ waters we observed higher cell mortality and lysis rates than those observed at the FF and CE stations, resulting in higher values of DOC production. Also, the significant relationship between PER and lysis rates observed indicated a significant proportion of the $\mathrm{P}_{\mathrm{DOC}}$ excreted to be the result of phytoplankton cell 
death. However, lysis explained less than $40 \%$ of the variability in PER, implying that other processes such as cell carbon exudation, reported to increase during nutrient limitation (e.g. Bratbak and Thingstad, 1985) were also responsible for the $\mathrm{P}_{\mathrm{DOC}}$ observed. Even though we were not able to analyze whether other processes as cell exudation may be involved in the DOC production by phytoplankton, we stressed that $\mathrm{P}_{\mathrm{DOC}}$ was significantly related to cell lysis rates, indicating an active participation of cell mortality processes in the DOC production by phytoplankton.

A high release of dissolved organic carbon produced by the senescent phytoplankton population found in anticyclonic eddies explains the higher abundance of heterotrophic bacteria in the AEs, consistent with the role of DOC as a substrate for heterotrophic bacteria growth (Kirchman et al., 1991; Norrman et al., 1995; Carlson and Ducklow, 1996; Kirchman and Rich, 1997). Despite that, Baltar et al. (2010) studied the bacterial dynamics in the same eddy systems but including deeper layers down to $1000 \mathrm{~m}$ depth and found prokaryotic activity being significantly lower in the AEs. We also found unexpectedly lower HB cell viability in AEs despite higher $\mathrm{P}_{\mathrm{DOC}}$ suggesting that bacteria are also affected by environmental changes at $\mathrm{AE}$. Limitation by inorganic nutrients such as phosphorus could influence the viability of HB (Lasternas et al., 2010). Indeed, nutrient supply has been shown to explain variability in bacterial activity in the Atlantic Ocean (Gasol et al., 2009), and the negative relationship between the \% DC of Synechococcus sp. and the \% LC of HB found here may indicate competition for phosphorus in the anticyclonic eddy systems (Zubkov et al., 2007; Lasternas et al., 2010). Flagellates and dinoflagellates may also be limited by DIP in AEs, as observed in systems with low DIP availability (Thingstad et al., 1998; Lasternas et al., 2010). Lasternas et al. (2010) found in the Mediterranean Sea (a system limited by DIP) that the percentage of living cells of dinoflagellates, heterotrophic bacteria and Synechococcus sp. was strongly related to DIP, and competition for this nutrient was important in structuring the phytoplankton community composition. Moreover, the low values of DIP in FF stations indicated that this nutrient must have been limiting phytoplankton biomass in that area. We found a significant positive relationship between bacterial cell viability and the ammonium concentration, indicating that ammonium, which stimulates bacterial activity and growth efficiency (Bratbak, 1987; Kroer et al., 1993), could be another important nutrient controlling bacteria in the eddy systems. Moreover, the significantly higher ammonium concentration found in the AEs indicated intense recycling processes resulting in a larger regenerated production than at FF or CE stations, which is in accordance with the highest pressure on bacteria by protists observed in the AEs by Boras et al. (2010).

\subsection{Phytoplankton dissolved organic carbon production within the eddy systems and the anticyclonic forcing}

The results presented provide evidence that the anticyclonic system studied generated environmental perturbations stressing phytoplankton communities in the early stages of anticyclone eddy development in the Canary Current region. While phytoplankton production and biomass were higher in both cyclonic and anticyclonic eddies than at waters outside the eddies (FF), biological processes were highly modified by downstream dynamics in the AEs affecting the pathway of the dissolved organic carbon produced by the phytoplankton community.

The anticyclonic eddies studied here could be defined as transient systems between moderately productive waters and oligotrophic waters that prevail at the FF stations at this zone of the NE Atlantic. During its formation, anticyclonic eddies are fed by productive waters generated at the Canary Current, which can support higher production and biomass than the common NE Atlantic oligotrophic waters (Barton et al., 1998; Sangrà et al., 2007). However, active downwelling in the AEs deprive the system of nutrients, resulting in a progressive oligotrophication of the eddies that entailed, in our study, the predominance of smaller phytoplanktonic cells and senescent populations of large photosynthetic cells.

Here, we showed that the perturbations that occurred at the early-stage anticyclonic eddies shed by the Canary Islands, mainly active downwelling, result in increased phytoplankton cell mortality, particularly affecting diatoms and other larger phytoplankton cells that influence carbon flux (Kirchman et al., 1991; Agustí et al., 1998). The reduction of the large, rapidly sinking phytoplankton and active actors in the long-term sequestration of atmospheric $\mathrm{CO}_{2}$ in the ocean interior (Smetacek, 1985, 1999; Martin et al., 2011), such as diatom populations along with the increasing picophytoplankton, should weaken the biological pump capacity of AEs (Michaels and Silver, 1988; Legendre and Le Fèvre, 1995). Moreover, the increased phytoplankton cell mortality and lysis observed here strongly induced a large $\mathrm{P}_{\mathrm{DOC}}$ release in the middle of the AEs, which ought to favor the microbial loop (Pomeroy, 1974; Azam et al., 1983; Legendre and Le Fèvre, 1995).

Although the consequences of the $\mathrm{CE}$ for the carbon fluxes have been well documented, those of anticyclonic systems remain more erratic. While the reduction of phytoplankton production and biomass in $\mathrm{AE}$ systems has been reported in the past (Falkowski et al., 1991; McGillicuddy et al., 1998), some AE systems have been recently described as being able to enhance phytoplankton biomass under certain conditions (McGillicuddy et al., 2007; Sangrà et al., 2009). Here, we report no differences in phytoplankton production between $\mathrm{AE}$ and $\mathrm{CE}$ systems in the Canary eddy field. However, the oligotrophication process observed in anticyclonic eddies was linked to a shift towards picoautotrophs, the aging and 
senescence of the microphytoplankton cells, with an overall increase in lysis rates, and an increase in the release of dissolved organic carbon compared to cyclonic eddies. These results highlight the importance of examining the consequences of eddy dynamics on phytoplankton cell status, which can affect phytoplankton communities and the partitioning of carbon flow between particulate and dissolved pathways, with fundamental consequences for carbon flow in the ocean.

Acknowledgements. This research is a contribution to the project RODA (CTM-2004-06842-CO3-O2 and O3) and the project MEDEICG (CTM2009-07013) funded by the Spanish Ministry of Science and Innovation. We thank the crew of the R/V Hespérides for their help during the RODA cruise. S. L. was supported by a EUR-OCEANS fellowship.

Edited by: M. Dai

\section{References}

Agawin, N. S. R., Duarte, C. M., and Agustí, S.: Nutrient and Temperature Control of the Contribution of Picoplankton to Phytoplankton Biomass and Production, Limnol. Oceanogr., 45, 591$600,2000$.

Agustí, S.: Viability and niche segregation of Prochlorococcus and Synechococcus cells across the Central Atlantic Ocean, Aquat. Microb. Ecol., 36, 53-59, doi:10.3354/ame036053, 2004.

Agustí, S. and Duarte, C. M.: Strong Seasonality in Phytoplankton Cell Lysis in the NW Mediterranean Littoral, Limnol. Oceanogr., 45, 940-947, 2000.

Agustí, S. and Duarte, C. M.: Addressing uncertainties in the assessment of phytoplankton lysis rates in the sea, Limnol. Oceanogr., 47, 921-924, 2002.

Agustí, S. and Sánchez, M. C.: Cell Viability in Natural Phytoplankton Communities Quantified by a Membrane Permeability Probe, Limnol. Oceanogr., 47, 818-828, 2002.

Agustí, S., Satta, M. P., Mura, M. P., and Benavent, E.: Dissolved Esterase Activity as a Tracer of Phytoplankton Lysis: Evidence of High Phytoplankton Lysis Rates in the Northwestern Mediterranean, Limnol. Oceanogr., 43, 1836-1849, 1998.

Agustí, S., Duarte, C. M., Vaqué, D., Hein, M., Gasol, J. M., and Vidal, M.: Food-web structure and elemental (C, N and P) fluxes in the eastern tropical North Atlantic, Deep Sea Res. II, 48, 22952321, doi:10.1016/S0967-0645(00)00179-X, 2001.

Alonso-González, I. J., Arístegui, J., Lee, C., and Calafat, A.: Regional and temporal variability of sinking organic matter in the subtropical northeast Atlantic Ocean: a biomarker diagnosis, Biogeosciences, 7, 2101-2115, doi:10.5194/bg-7-21012010, 2010.

Alonso-Laita, P. and Agustí, S.: Contrasting patterns of phytoplankton viability in the subtropical NE Atlantic Ocean. Aquat. Microb. Ecol., 43, 67-78, doi:10.3354/ame043067, 2006.

Arístegui, J. and Montero, M. F.: Temporal and spatial changes in plankton respiration and biomass in the Canary Islands region: the effect of mesoscale variability, J. Marine Syst., 54, 65-82, doi:10.1016/j.jmarsys.2004.07.004, 2005.
Arístegui, J., Tett, P., Hernández-Guerra, A., Basterretxea, G., Montero, M. F., Wild, K., Sangrá, P., Hernández-Leon, S., Canton, M., García-Braun, J. A., Pacheco, M., and Barton, E. D.: The influence of island-generated eddies on chlorophyll distribution: a study of mesoscale variation around Gran Canaria, Deep Sea Res. I, 44, 71-96, doi:10.1016/S0967-0637(96)00093-3, 1997.

Arístegui, J., Barton, E., Montero, M., García-Muñoz, M., and Escánez, J.: Organic carbon distribution and water column respiration in the NW Africa-Canaries Coastal Transition Zone, Aquat. Microb. Ecol., 33, 289-301, doi:10.3354/ame033289, 2003.

Azam, F., Fenchel, T., Field, J., Gray, J., Meyer, L., and Thingstad, F.: The ecological role of water column microbes in the sea, Mar. Ecol.-Prog. Ser., 10, 257-263, 1983.

Baltar, F., Aristegui, J., Gasol, J. M., Lekunberri, I., and Herndl, G. J.: Mesoscale eddies: hotspots of prokaryotic activity and differential community structure in the ocean, ISME J., 4, 975-988, 2010.

Barbesti, S., Citterio, S., Labra, M., Baroni, M. D., Neri, M. G., and Sgorbati, S.: Two and three-color fluorescence flow cytometric analysis of immunoidentified viable bacteria, Cytometry, 40, 214-218, 2000.

Barton, E. D., Arístegui, J., Tett, P., Cantón, M., García-Braun, J., Hernández-León, S., Nykjaer, L., Almeida, C., Almunia, J., Ballesteros, S., Basterretxea, G., Escánez, J., García-Weill, L., Hernández-Guerra, A., López-Laatzen, F., Molina, R., Montero, M. F., Navarro-Pérez, E., Rodríguez, J. M., van Lenning, K., Vélez, H., and Wild, K.: The transition zone of the Canary Current upwelling region, Prog. Oceanogr., 41, 455-504, doi:10.1016/S0079-6611(98)00023-8, 1998.

Basterretxea, G., Barton, E. D., Tett, P., Sangrá, P., Navarro-Perez, E., and Arístegui, J.: Eddy and deep chlorophyl maximum response to wind-shear in the lee of Gran Canaria, Deep Sea Res. I, 49, 1087-1101, doi:10.1016/S0967-0637(02)00009-2, 2002.

Benitez-Nelson, C. R. and McGillicuddy Jr., D. J.: Mesoscale physical-biological-biogeochemical linkages in the open ocean: An introduction to the results of the E-Flux and EDDIES programs, Deep Sea Res. II, 55, 1133-1138, doi:10.1016/j.dsr2.2008.03.001, 2008.

Berges, J. A. and Falkowski, P. G.: Physiological Stress and Cell Death in Marine Phytoplankton: Induction of Proteases in Response to Nitrogen or Light Limitation, Limnol. Oceanogr., 43, 129-135, 1998.

Bidigare, R. R., Benitez-Nelson, C., Leonard, C. L., Quay, P. D., Parsons, M. L., Foley, D. G., and Seki, M. P.: Influence of a cyclonic eddy on microheterotroph biomass and carbon export in the lee of Hawaii, Geophys. Res. Lett., 30, 1318, doi:10.1029/2002GL016393, 2003.

Boras, J. A., Sala, M. M., Baltar, F., Aristegui, J., Duarte, C. M., and Vaqué, D.: Effect of viruses and protists on bacteria in eddies of the Canary Current region (subtropical northeast Atlantic), Limnol. Oceanogr., 55, 885-898, 2010.

Bratbak, G.: Carbon flow in an experimental microbial ecosystem. Mar. Ecol.-Prog. Ser., 36, 267-276, 1987.

Bratbak, G. and Thingstad, T. F.: Phytoplankton-bacteria interactions: an apparent paradox? Analysis of a model system with both competition and commensalism, Mar. Ecol.-Prog. Ser., 25, 23-30, 1985. 
Brussaard, C. P. D., Riegman, R., Noordeloos, A. A. M., Cadée, G. C., Witte, H., Kop, A. J., Nieuwland, G., Van Duyl, F. C., and Bak, R. P. M.: Effects of grazing, sedimentation and phytoplankton cell lysis on the structure of a coastal pelagic food web, Mar. Ecol.-Prog. Ser., 123, 259-271, 1995.

Carlson, C. and Ducklow, H.: Growth of bacterioplankton and consumption of dissolved organic carbon in the Sargasso Sea, Aquat. Microb. Ecol., 10, 69-85, doi:10.3354/ame010069, 1996.

Ewart, C. S., Meyers, M. K., Wallner, E. R., McGillicuddy Jr., D. J., and Carlson, C. A.: Microbial dynamics in cyclonic and anticyclonic mode-water eddies in the northwestern Sargasso Sea, Deep Sea Res. II, 55, 1334-1347, doi:10.1016/j.dsr2.2008.02.013, 2008.

Falcioni, T., Papa, S., and Gasol, J. M.: Evaluating the FlowCytometric Nucleic Acid Double-Staining Protocol in Realistic Situations of Planktonic Bacterial Death, Appl. Environ. Microb., 74, 1767-1779, doi:10.1128/AEM.01668-07, 2008.

Falkowski, P. G., Ziemann, D., Kolber, Z., and Bienfang, P. K.: Role of eddy pumping in enhancing primary production in the ocean, Nature, 352, 55-58, doi:10.1038/352055a0, 1991.

Garçon, V. C., Oschlies, A., Doney, S. C., McGillicuddy Jr., D. J., and Waniek, J.: The role of mesoscale variability on plankton dynamics in the North Atlantic, Deep Sea Res. II, 48, 2199-2226, doi:10.1016/S0967-0645(00)00183-1, 2001.

Gasol, J. M., Vázquez-Domínguez, E., Vaqué, D., Agustí, S., and Duarte, C. M.: Bacterial activity and diffusive nutrient supply in the oligotrophic Central Atlantic Ocean, Aquat. Microb. Ecol., 56, 1-12, doi:10.3354/ame01310, 2009.

González-Dávila, M., Santana-Casiano, J. M., de Armas, D., Escánez, J., and Suarez-Tangil, M.: The influence of island generated eddies on the carbon dioxide system, south of the Canary Islands, Mar. Chem., 99, 177-190, doi:10.1016/j.marchem.2005.11.004, 2006.

Grégori, G., Citterio, S., Ghiani, A., Labra, M., Sgorbati, S., Brown, S., and Denis, M.: Resolution of Viable and Membrane-Compromised Bacteria in Freshwater and Marine Waters Based on Analytical Flow Cytometry and Nucleic Acid Double Staining, Appl. Environ. Microb., 67, 4662-4670, doi:10.1128/AEM.67.10.4662-4670.2001, 2001.

Hansen, H. P. and Koroleff, F.: Determination of nutrients, in: Methods of seawater analysis, edited by: Grasshoff, K., Kremling, K., and Ehrhardt, M., Weinheim, Wiley-VCH Verlag, 159-228, 1999.

Jia, Y., Calil, P. H. R., Chassignet, E. P., Metzger, E. J., Potemra, J. T., Richards, K. J., and Wallcraft, A. J.: Generation of mesoscale eddies in the lee of the Hawaiian Islands, J. Geophys. Res., 116, C11009, doi:201110.1029/2011JC007305, 2011.

Jiménez, B., Sangrà, P., and Mason, E.: A numerical study of the relative importance of wind and topographic forcing on oceanic eddy shedding by tall, deep water islands, Ocean Model., 22, 146-157, 2008.

Kara, A. B., Rochford, P. A., and Hurlburt, H. E.: An optimal definition for ocean mixed layer depth, J. Geophys. Res., 105, 1680316821, doi:200010.1029/2000JC900072, 2000.

Kérouel, R. and Aminot. A.: Fluorometric determination of ammonia in sea and estuarine waters by direct segmented flow analysis, Mar. Chem., 57, 265-275, 1997.

Kirchman, D. L., Suzuki, Y., Garside, C., and Ducklow, H. W.: High turnover rates of dissolved organic carbon during a spring phyto- plankton bloom, Nature, 352, 612-614, doi:10.1038/352612a0, 1991.

Kirchman, D. L. and. Rich, J. H.: Regulation of Bacterial Growth Rates by Dissolved Organic Carbon and Temperature in the Equatorial Pacific Ocean, Microb. Ecol., 33, 11-20, doi:10.1007/s002489900003, 1997.

Kroer, N.: Bacterial Growth Efficiency on Natural Dissolved Organic Matter, Limnol. Oceanogr., 38, 1282-1290, 1993.

Lasternas, S., Agustí, S., and Duarte, C. M.: Phyto- and bacterioplankton abundance and viability and their relationship with phosphorus across the Mediterranean Sea, Aquat. Microb. Ecol., 60, 175-191, doi:10.3354/ame01421, 2010.

Legendre, L. and Le Fèvre, J.: Microbial food webs and the export of biogenic carbon in oceans, Aquat. Microb. Ecol., 9, 69-77, 1995.

Llabrés, M. and Agustí, S.: Picophytoplankton Cell Death Induced by UV Radiation: Evidence for Oceanic Atlantic Communities, Limnol. Oceanogr., 51, 21-29, 2006.

Marie, D., Simon, N., and Vaulot, D.: Phytoplankton cell counting by flow cytometry, Algal culturing techniques, 253-268, 2005.

Martin, A. P. and Richards, K. J.: Mechanisms for vertical nutrient transport within a North Atlantic mesoscale eddy, Deep Sea Res. II, 48, 757-773, doi:10.1016/S0967-0645(00)00096-5, 2001.

Martin, P., Lampitt, R. S., Jane Perry, M., Sanders, R., Lee, C., and D'Asaro, E.: Export and mesopelagic particle flux during a North Atlantic spring diatom bloom, Deep Sea Res. I, 58, 338-349, doi:10.1016/j.dsr.2011.01.006, 2011.

Martin-Jézéquel, V., Hildebrand, M., and Brzezinski, M. A.: Silicon metabolism in diatoms: Implications for growth, J. Phycol., 36, 821-840, doi:10.1046/j.1529-8817.2000.00019.x, 2003.

Mason, E., Colas, F., Molemaker, J., Shchepetkin, A. F., Troupin, C., McWilliams, J. C., and Sangrà, P.: Seasonal variability of the Canary Current: A numerical study. J. Geophys. Res., 116, C06001, doi:201110.1029/2010JC006665, 2011.

Mathis, J. T., Pickart, R. S., Hansell, D. A., Kadko, D., and Bates, N. R.: Eddy transport of organic carbon and nutrients from the Chukchi Shelf: Impact on the upper halocline of the western Arctic Ocean, J. Geophys. Res., 112, C05011, doi:10.1029/2006JC003899, 2007.

McGillicuddy Jr., D. J., Robinson, A. R., Siegel, D. A., Jannasch, H. W., Johnson, R., Dickey, T. D., McNeil, J., Michaels, A. F., and Knap, A. H.: Influence of mesoscale eddies on new production in the Sargasso Sea, Nature, 394, 263-266, 1998.

McGillicuddy Jr., D. J., Johnson, M., R., Siegel, D. A., Michaels, A. F., Bates, N. R., and Knap, A. H.: Mesoscale variations of biogeochemical properties in the Sargasso Sea, J. Geophys. Res., 104, 13381-13394, doi:199910.1029/1999JC900021, 1999.

McGillicuddy Jr., D. J., Anderson, L. A., Bates, N. R., Bibby, T., Buesseler, K. O., Carlson, C. A., Davis, C. S., Ewart, C., Falkowski, P. G., Goldthwait, S. A., Hansell, D. A., Jenkins, W. J., Johnson, R., Kosnyrev, V. K., Ledwell, J. R., Li, Q. P., Siegel, D. A., and Steinberg, D. K.: Eddy/Wind Interactions Stimulate Extraordinary Mid-Ocean Plankton Blooms, Science, 316, 1021-1026, doi:10.1126/science.1136256, 2007.

Michaels, A. F. and Silver, M. W.: Primary production, sinking fluxes and the microbial food web, Deep Sea Res. A, 35, 473490, doi:10.1016/0198-0149(88)90126-4, 1988.

Morán, X. A. and Estrada, M.: Phytoplanktonic DOC and POC production in the Bransfield and Gerlache Straits as derived from 
kinetic experiments of 14C incorporation, Deep Sea Res. II, 49, 769-786, 2002.

Myklestad, S.: Production of carbohydrates by marine planktonic diatoms. II. Influence of the ratio in the growth medium on the assimilation ratio, growth rate, and production of cellular and extracellular carbohydrates by Chaetoceros affinis var. willei (Gran) Hustedt and Skeletonema costatum (Grev.) Cleve, J. Exp. Mar. Biol. Ecol., 29, 161-179, doi:10.1016/0022-0981(77)90046-6, 1977.

Norrman, B., Zweifel, U. L., Hopkinson, C. S., and Fry, B.: Production and utilization of dissolved organic carbon during an experimental diatom bloom, Limnol. Oceanogr., 40, 898-907, 1995.

Oschlies, A. and Garçon, V.: Eddy-induced enhancement of primary production in a model of the North Atlantic Ocean, Nature, 394, 266-269, 1998.

Owen, R. W.: Fronts and eddies in the sea: mechanisms, interactions and biological effects, in: Analysis of marine ecosystems, edited by: Longhurst, A. R., Academic Press, New York, 197233, 1981

Parsons, T. R., Maita, Y., and Lalli, C. M.: A manual of chemical and biological methods for seawater analysis, Pergamon Press, Oxford, 1984

Piedeleu, M., Sangrà, P., Sánchez-Vidal, A., Fabrés, J., Gordo, C., and Calafat, A.: An observational study of oceanic eddy generation mechanisms by tall deep-water islands (Gran Canaria), Geophys. Res. Lett., 36, L14605 , doi:200910.1029/2008GL037010, 2009

Platt, T., Rao, D. V. S., and Irwin, B.: Photosynthesis of picoplankton in the oligotrophic ocean, Nature, 301, 702-704, doi:10.1038/301702a0, 1983 .

Pomeroy, L. R.: The ocean's foodweb: a changing paradigm, Bioscience, 24, 499-504, 1974.

Proctor, L. M. and Fuhram, J. A.: Roles of viral infection in organic particle flux, Marine, 69, 133-142, 1991.

Rodríguez, J., Tintore, J., Allen, J. T., Blanco, J. M., Gomis, D., Reul, A., Ruiz, J., Rodríguez, V., Echevarria, F., and Jiménez-Gomez, F.: Mesoscale vertical motion and the size structure of phytoplankton in the ocean, Nature, 410, 360-363, doi:10.1038/35066560, 2001.

Rodríguez, F., Varela, M., Fernández, E., and Zapata, M.: Phytoplankton and pigment distributions in an anticyclonic slope water oceanic eddy (SWODDY) in the southern Bay of Biscay, Mar. Biol., 143, 995-1011, doi:10.1007/s00227-003-1129-1, 2003.

Sangrà, P., Pelegri, J. L., Hernández-Guerra, A., Arregui, I., Martin, J. M., Marrero-Diaz, A., Martinez, A., Ratsimandresy, A. W., and Rodríguez-Santana, A.: Life history of an anticyclonic eddy, J. Geophys. Res., 110, C03021, doi:10.1029/2004JC002526, 2005.

Sangrà, P., Auladell, M., Marrero-Díaz, A., Pelegrí, J. L., FraileNuez, E., Rodríguez-Santana, A., Martín, J. M., Mason, E., and Hernández-Guerra, A.: On the nature of oceanic eddies shed by the Island of Gran Canaria, Deep Sea Res. I, 54, 687-709, doi:10.1016/j.dsr.2007.02.004, 2007.
Sangrà, P., Pascual, A., Rodríguez-Santana, A., Machín, F., Mason, E., McWilliams, J. C., Pelegrí, J. L., Dong, C., Rubio, A., Arístegui, J., Marrero-Díaz, Á., Hernández-Guerra, A., Martínez-Marrero, A., and Auladell, M.: The Canary Eddy Corridor: A major pathway for long-lived eddies in the subtropical North Atlantic, Deep Sea Res. I, 56, 2100-2114, doi:10.1016/j.dsr.2009.08.008, 2009.

Siegel, S. and Castellan, N. J.: Non-parametric statistics for the behavioural sciences, McGraw Hill Company, New York, 1988.

Siegel, D. A, McGillicuddy, D. J., and Fields, E. A.: Mesoscale eddies, satellite altimetry, and new production in the Sargasso Sea, J. Geophys. Res., 104, 13359-13379, 1999.

Smayda, T. J. and Reynolds, C. S.: Community assembly in marine phytoplankton: Application of recent models to harmful dinoflagellate blooms, J. Plankton Res., 23, 447-461, doi:10.1093/plankt/23.5.447, 2001.

Smetacek, V. S.: Role of sinking in diatom life-history cycles: ecological, evolutionary and geological significance, Mar. Biol., 84 239-251, doi:10.1007/BF00392493, 1985.

Smetacek, V. S.: Diatoms and the ocean carbon cycle, Protist, 250, 25-32, 1999.

Smith, C. L., Richards, K. J., and Fasham, M. J. R.: The impact of mesoscale eddies on plankton dynamics in the upper ocean, Deep Sea Res. I, 43, 1807-1832, doi:10.1016/S0967-0637(96)00035$0,1996$.

Steemann-Nielsen, E. J.: The use of radioactive carbon (14C) for measuring organic production in the sea, Cons. Perm. Int. Explor Mer., 18, 117-140, 1952.

Tarran, G. A., Zubkov, M. V., Sleigh, M. A., Burkill, P. H., and Yallop, M.: Microbial community structure and standing stocks in the NE Atlantic in June and July of 1996, Deep Sea Res. II, 48, 963-985, doi:10.1016/S0967-0645(00)00104-1, 2001.

Thingstad, T. F., Zweifel, U. L., and Rassoulzadegan, F.: P limitation of heterotrophic bacteria and phytoplankton in the Northwest Mediterranean. Limnol. Oceanogr., 43, 88-94, 1998.

Vaillancourt, R. D., Marra, J., Seki, M. P., Parsons, M. L., and Bidigare, R. R.: Impact of a cyclonic eddy on phytoplankton community structure and photosynthetic competency in the subtropical North Pacific Ocean, Deep Sea Res. I, 50, 829-847, doi:10.1016/S0967-0637(03)00059-1, 2003.

Zubkov, M. V., Mary, I., Woodward, E. M. S., Warwick, P. E., Fuchs, B. M., Scanlan, D. J., and Burkill, P. H.: Microbial control of phosphate in the nutrient-depleted North Atlantic subtropical gyre, Environ. Microbiol., 9, 2079-2089, doi:10.1111/j.14622920.2007.01324.x, 2007. 